\title{
Genetic Structure of Tetraploid Italian and Westerwolds Ryegrasses (Lolium spp.) as Revealed by Enzyme and ISSR Polymorphism
}

\author{
Maria Krzakowa $^{1}$ and Agnieszka Sutkowska ${ }^{2}$ \\ 1. Department of Genetics, Institute of Experimental Biology, Adam Mickiewicz University, Umultowska 89, Poznań 61-614, Poland \\ 2. Department of Plant Breeding and Seed Science, University of Agriculture in Kraków, Lobzowska 24, Kraków 31-140, Poland
}

\begin{abstract}
The genetic variation of Italian ryegrass (Lolium multiflorum Lam.) and westerwolds ryegrass (L. westerwoldicum Breakw.) was investigated in eight tetraploid cultivars originated from Poland. The 337 individual seedlings, cultivated in uniform greenhouse conditions, were tested with horizontal gel electrophoresis according to five enzyme systems: diaforase (DIA), superoxide dismutase (SOD), glutamate oxalacetate transaminase (GOT), peroxidise (PX) and phosphogluco isomerise (PGI), which were used to array allelic diversity at five polymorphic loci. The estimation of genetic diversity in 64 plants of the same cultivars was studied using inter simple sequence repeats (ISSRs) as molecular marker. The genetic variation described by ISSR suggests that the polymorphism detected appears to be poorly informative at the taxonomic level. For statistical analysis, unweighted pair group method with arithmetic mean (UPGMA) based dendrograms and minimum spanning trees were constructed using Nei's distance and Jaccard's similarity coefficient.
\end{abstract}

Key words: Lolium spp., tetraploid cultivars, genetic structure, enzyme electrophoresis, inter simple sequence repeats markers.

\section{Introduction}

Italian ryegrass (Lolium multiflorum Lam.) is a fodder grass. This species, known for its good taste (due to high sugar content), is also valued as fodder in the form of hay and silage, so it is grown intensively in Asia, America, Europe and New Zealand.

In recent years, scientists have searched for markers to describe its genetic variation with the use of many techniques, such as enzyme electrophoresis and DNA sequencing. In genetic research on populations of $L$. multiflorum, mostly randomly amplified polymorphic DNA (RAPD), amplified fragment length polymorphism (AFLP) and simple sequence repeats (SSR) markers have been used so far [1-4]. In this study, inter simple sequence repeats (ISSR) markers have been chosen instead, as this method has most of the benefits of SSR and AFLP, and it proves to be a

Corresponding author: Maria Krzakowa, professor, research fields: genetic variability of natural and cultivated plant populations (bryophytes, forest trees and grasses). good method for genetic diversity detection in other monocot crops, e.g., rice [5-7], rye [8], triticale [9, 10] and barley [11], as well as grasses of the genus Bromus [12]. ISSR segregates mostly as dominant marker following simple Mendelian inheritance and also enables distinction between homozygotes and heterozygotes.

Westerwolds ryegrass (L. westerwoldicum, syn. $L$. multiflorum ssp. westerwoldicum) is also an annual fodder grass, originating from the Westerwolde region in the Netherlands. This species is highly valued by breeders, so its local cultivars have been developed in many countries, including Poland. The variation of its Polish cultivars has been described in respect of morphological and chemical characters [13], but no genetic studies have been done.

In spite of intensive application of molecular methods, enzymatic studies of Lolium species, including L. multiflorum are still relevant [14]. They are used both in considerations of difference between 
species [15] and in tracing of the mechanisms of their inheritance [16].

As the genetic variation of $L$. westerwoldicum has not been investigated till now, this study was aimed to find some markers for comparison of the two species in question.

\section{Materials and Methods}

\subsection{Plant Materials}

Seedlings of three Polish cultivars of $L$. westerwoldicum, i.e., Kaja (KA), Koga (KO), Telga (TE), and five cultivars of L. multiflorum, i.e., Atos (A), Gaza (GA), Gisel (G), Turtetra (TU) and cultivar 604 (604), were grown from seeds in the same greenhouse conditions. The seeds were procured from breeding companies: Małopolska Plant Breeding HBP Ltd. (Kraków), Bartrążek Plant Breeding Ltd. (Olsztyn) and Danko Plant Breeding Ltd. (Szelejewo).

\subsection{Electrophoretic Separation of Enzymes}

Individual plants, at least 30 of each cultivar: KA $(N=58), \mathrm{KO}(N=30), \mathrm{TE}(N=30), \mathrm{A}(N=60), \mathrm{GA}$ $(N=30), \mathrm{G}(N=31), \mathrm{TU}(N=66)$ and $604(N=32)$, were studied in respect of five enzymatic systems: diaphorase (DIA), superoxide dismutase (SOD), glutamic oxaloacetic transaminase (GOT), peroxidase (PX) and phosphogluco isomerase (PGI). Two leaves from individual plants were homogenised in double-distilled water for DIA, SOD, GOT and PX. Plants prepared for the PGI enzyme system were homogenized in $0.12 \mathrm{M}$ Tris-HCl, $\mathrm{pH}$ 7.5. Electrophoresis was conducted in $11 \%$ starch gel (Sigma) prepared on the basis of lithium-boric buffer system, $\mathrm{pH}$ 8.1. Band patterns were visualised by a method previously used [14]. Electrophoretically detected phenotypes were used to calculate the genetic parameters: observed heterozygosity $\left(H_{o}\right)$, expected heterozygosity $\left(H_{e}\right)$, inbreeding coefficient $(F)$ and polymorphic index $\left(P_{g}\right)$. The genetic distances between cultivar populations were calculated on the basis of allele frequency according to Nei [17] and illustrated by minimum spanning trees and dendrograms.

\subsection{Molecular Analysis}

DNA was isolated from 64 plants (eight plants of each cultivar) by using Genomic Mini AX plant kit (A\&A Biotechnology) according to the manufacturer's instructions. In polymerase chain reaction (PCR), Fermentas reagents were used. Amplifications were conducted in $25 \mu \mathrm{L}$ of reaction volume containing $100 \mathrm{ng}$ of DNA, and polymerase buffer was composed of $1.5 \mathrm{mM} \mathrm{MgCl} 2,1 \mathrm{mM}$ NTP, $0.25 \mathrm{mM}$ of primer and 1.4 units of Taq polymerase. The sequences of primers were taken from Stepansky et al. [18]. PCR amplification was performed by 2720 thermal cycler (Applied Biosystems). Amplification products were separated in $1.5 \%$ agarose gel with ethidium bromide. The gels were visualised using the ImageMaster ${ }^{\mathbb{R}}$ VDS (Pharmacia Biotech) and Liscap Capture ver. 1.0 software. For analysis of band patterns, GelScan ver. 1.43 (Kucharczyk TE) software was used. Each plant subjected to ISSR analysis was regarded as an operational taxonomic unit (OTU). The 302 ISSR bands for 64 OTUs were encoded as a binary data matrix (with " 1 " indicating the presence and " 0 " the absence). The data were used to calculate the matrix of Jaccard's similarity coefficients and to generate a dendrogram by unweighted pair group method with arithmetic mean (UPGMA), using NTSYS ver. 2.11a software [19].

\section{Results and Discussion}

\subsection{DIA (E.C.1.6.4.3)}

All the populations were polymorphic in respect of three alleles of a single locus. The minimum spanning tree based on frequencies of alleles (allozymes, Fig. 1) indicates high similarity of cultivars TU, GA and $\mathrm{KO}$, and of A and TE. Particularly noteworthy is cultivar $\mathrm{KA}$, which is the most distant genetically from the others. $P_{g}$ values ranged from 0.22 to 0.65 (see Table 1 for DIA and other enzyme systems). 


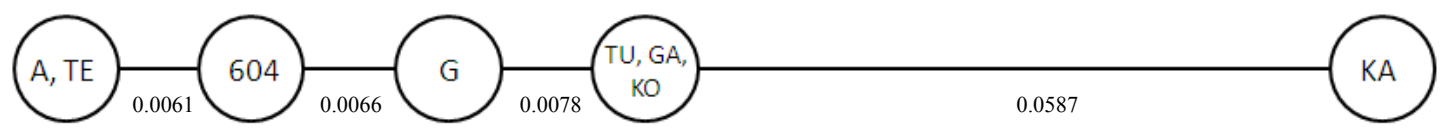

A

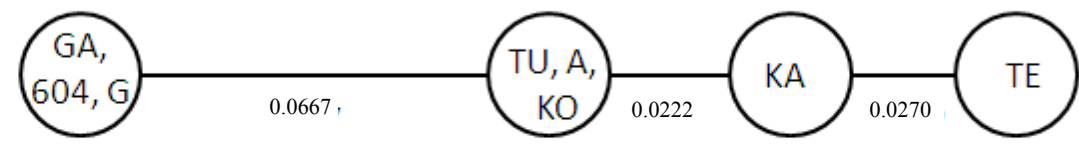

B

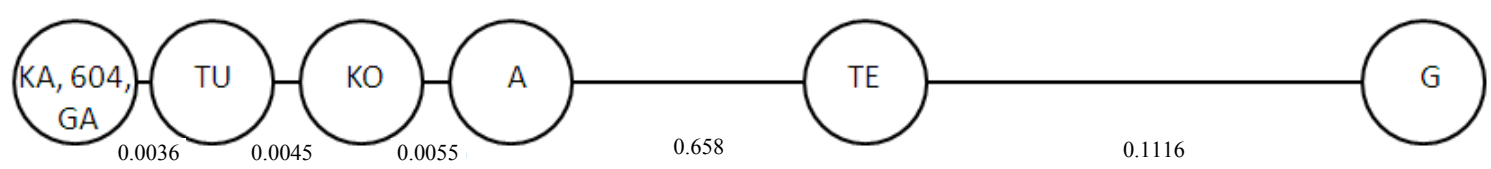

C

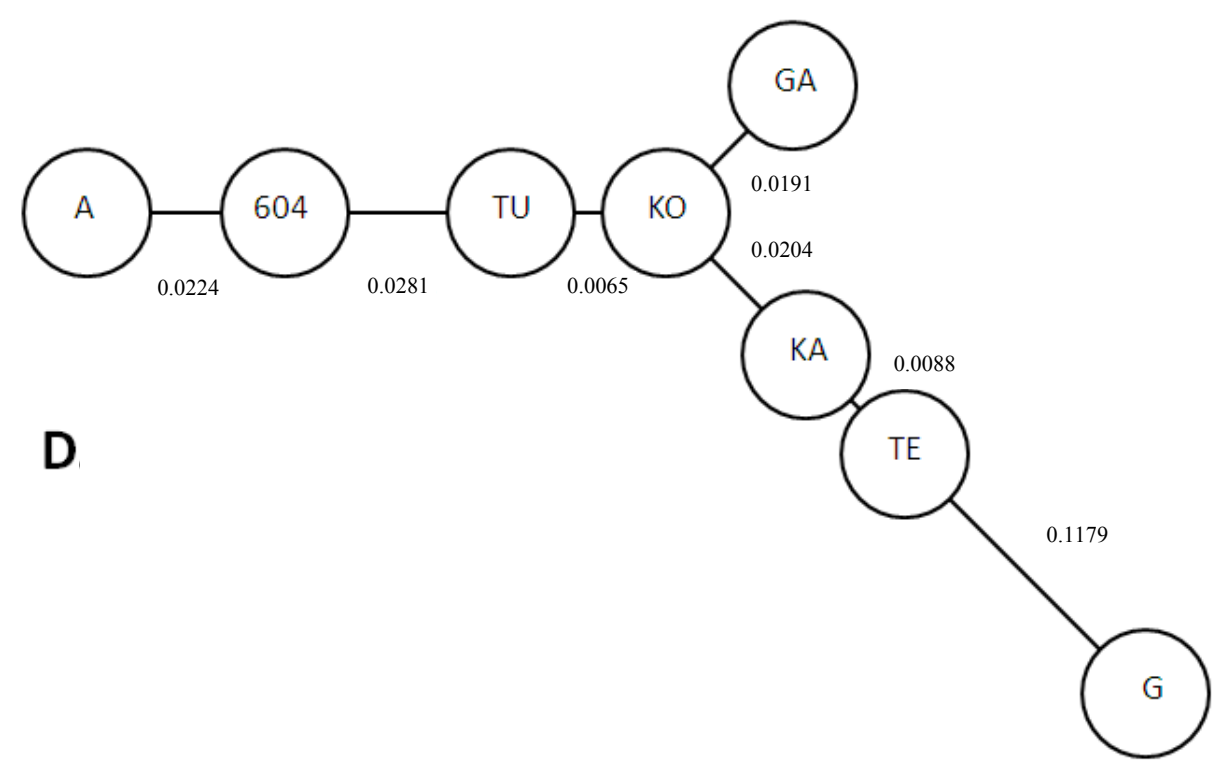

Fig. 1 The minimum spanning trees of genetic distances constructed for the four enzyme systems (A-DIA, B-GOT, C—SOD, D-PX) on the basis of gene frequency in eight cultivars. 

as Revealed by Enzyme and ISSR Polymorphism

Table 1 Genetic parameters for the eight $L$. multiflorum cultivars.

\begin{tabular}{|c|c|c|c|c|c|}
\hline Locus & Cultivars & $H_{e}$ & $H_{o}$ & $F$ & $P_{g}$ \\
\hline DIA D & 604 & 0.5547 & 1.0000 & -0.8028 & 0.2188 \\
\hline DIA D & A & 0.4922 & 0.8750 & -0.7778 & 0.2188 \\
\hline DIA D & $\mathrm{G}$ & 0.5000 & 0.7500 & -0.5000 & 0.4063 \\
\hline DIA D & GA & 0.4922 & 0.8750 & -0.7778 & 0.2188 \\
\hline DIA D & KA & 0.3750 & 0.5000 & -0.3333 & 0.5000 \\
\hline DIA D & $\mathrm{KO}$ & 0.4922 & 0.8750 & -0.7778 & 0.2188 \\
\hline DIA D & $\mathrm{TE}$ & 0.4922 & 0.3750 & 0.2381 & 0.6563 \\
\hline DIA D & TU & 0.4922 & 0.7500 & -0.7778 & 0.2188 \\
\hline GOT G & 604 & 0.2188 & 0.2500 & -0.1429 & 0.3750 \\
\hline GOT G & A & 0.1172 & 0.1250 & -0.0667 & 0.2188 \\
\hline GOT G & $\mathrm{G}$ & 0.2188 & 0.2500 & -0.1429 & 0.3750 \\
\hline GOT G & GA & 0.2188 & 0.2500 & -0.1429 & 0.3750 \\
\hline GOT G & $\mathrm{KA}$ & 0.2188 & 0.2500 & -0.1429 & 0.3750 \\
\hline GOT G & $\mathrm{KO}$ & 0.1172 & 0.1250 & -0.0667 & 0.2188 \\
\hline GOT G & $\mathrm{TE}$ & 0.3047 & 0.3750 & -0.2308 & 0.4688 \\
\hline GOT G & TU & 0.1172 & 0.1250 & -0.0667 & 0.2188 \\
\hline SOD S & 604 & 0.2188 & 0.2500 & -0.1429 & 0.3750 \\
\hline SOD S & A & 0.4297 & 0.6250 & -0.4545 & 0.4688 \\
\hline SOD S & $\mathrm{G}$ & 0.3750 & 0.2500 & 0.3333 & 0.5313 \\
\hline SOD S & GA & 0.2188 & 0.2500 & -0.1429 & 0.3750 \\
\hline SOD S & KA & 0.2188 & 0.2500 & -0.1429 & 0.3750 \\
\hline SOD S & $\mathrm{KO}$ & 0.3750 & 0.5000 & -0.3333 & 0.5000 \\
\hline SOD S & $\mathrm{TE}$ & 0.5000 & 1.0000 & -1.0000 & 0.0000 \\
\hline SOD S & $\mathrm{TU}$ & 0.3047 & 0.3700 & -0.2308 & 0.4688 \\
\hline PX X & 604 & 0.4766 & 0.6250 & -0.3115 & 0.6563 \\
\hline PX X & A & 0.5313 & 0.7500 & -0.4118 & 0.6250 \\
\hline PX X & $\mathrm{G}$ & 0.6641 & 1.0000 & -0.5059 & 0.6563 \\
\hline PX X & GA & 0.5703 & 0.6250 & -0.0959 & 0.6563 \\
\hline PX X & $\mathrm{KA}$ & 0.5547 & 0.6250 & -0.1268 & 0.6563 \\
\hline PX X & $\mathrm{KO}$ & 0.4688 & 0.5000 & -0.0667 & 0.5938 \\
\hline PX X & $\mathrm{TE}$ & 0.5547 & 0.8750 & -0.5775 & 0.4063 \\
\hline PX X & $\mathrm{TU}$ & 0.4297 & 0.3750 & -0.1263 & 0.5938 \\
\hline PGI P & 604 & 0.7656 & 1.0000 & -0.3061 & 0.7500 \\
\hline PGI P & A & 0.8359 & 1.0000 & -0.1963 & 0.8125 \\
\hline PGI P & G & 0.8125 & 0.8750 & -0.0769 & 0.7813 \\
\hline PGI P & GA & 0.7813 & 0.8750 & -0.1200 & 0.8438 \\
\hline PGI P & $\mathrm{KA}$ & 0.7578 & 0.8750 & -0.1546 & 0.7813 \\
\hline PGI P & $\mathrm{KO}$ & 0.8203 & 1.0000 & -0.2190 & 0.7813 \\
\hline PGI P & $\mathrm{TE}$ & 0.7578 & 0.8750 & -0.1546 & 0.6875 \\
\hline PGI P & $\mathrm{TU}$ & 0.7969 & 1.0000 & -0.2549 & 0.8125 \\
\hline
\end{tabular}

\subsection{SOD (E.C.2.6.12.1)}

The minimum spanning tree based on frequencies of two alleles of a single locus (Fig. 2) showed that cultivar $\mathrm{G}$ is the most distinct, characterized by the highest $P_{g}=0.53$. Three cultivars (KA, 604 and GA) do not differ in polymorphic index $P_{g}=0.37$.

\subsection{GOT (E.C.2.6.1.1)}

As shown in the minimum spanning tree based on frequencies of three alleles of a single locus (Fig. 3), cultivars GA, 604 and $G$ are the most similar to one another and distant genetically from the other populations. A similar group is composed of cultivars 
$\mathrm{TU}, \mathrm{A}$ and $\mathrm{KO}$, which do not differ in polymorphic index $P_{g}=0.22$. Overall, the polymorphism of populations was relatively low, as $P_{g}$ values ranged from 0.22 to 0.47 for cultivar TE.

\subsection{PX (E.C.1.11.1.7)}

The minimum spanning tree based on frequencies of two alleles of a single locus (Fig. 1D) showed the distinctness of cultivar G. The similarity of cultivars $\mathrm{TU}$ and $\mathrm{KO}$ is noticeable, like in the previous enzymatic systems. $P_{g}$ values varied from 0.40 to 0.66 .

Lolium plants contain PXs of anodal migration [20]. Less frequently, peroxidises of cathodal migration are detected in grasses [21]. Taking into account that PXs are contained mainly in cell walls, such a location results in their activity at early stages of defence reactions of the plant to pathogen attacks. Besides, PXs have proven to provide useful markers for analysing intra-specific differentiation, as well as differences between species [21, 22]. In this study, PXs were used to detect differences between cultivars, which were not detected in the other four enzymatic systems. Only in respect of PXs for the three cultivars of $L$. westerwoldicum (KA, KO and TE), close genetic similarity was found (Fig. 1D).

\subsection{PGI (E.C. 5.3.1.9)}

All the tetraploid cultivars used in this study show a high polymorphism of four alleles of one locus. Generally, the PGI dimer is a highly polymorphic enzyme system and although it is the most expensive to work with, it should be recommended for broader investigations, especially in Lolium species [22]. Estimation of genetic diversity was shown in Table 1. The populations differ in heterozygosity level. $P_{g}$ values ranged from 0.69 to 0.84 . Genetic differences among cultivars are illustrated by a dendrogram (Fig. 2). Cultivar $G$ is the most distant from others, which forms two subgroups. One of them is composed of two cultivars of L. westerwoldicum ( $\mathrm{KA}$ and $\mathrm{KO}$ ), while cultivars of L. multiflorum (604 and A) are accompanied by L. westerwoldicum TE. Examples of histograms generated for L. multiflorum GA and $L$. westerwoldicum (TE) were shown in Fig. 3.

ISSR-PCR was conducted with seven primers, but for analysis of the results, only those with the most readable band patterns (ISSR 01, ISSR 04, ISSR 05, ISSR 06 and ISSR 07) were used. The primers generated 2-12 products of various lengths, depending on the individual and primer. The total number of products of various lengths was as follows: 52 for
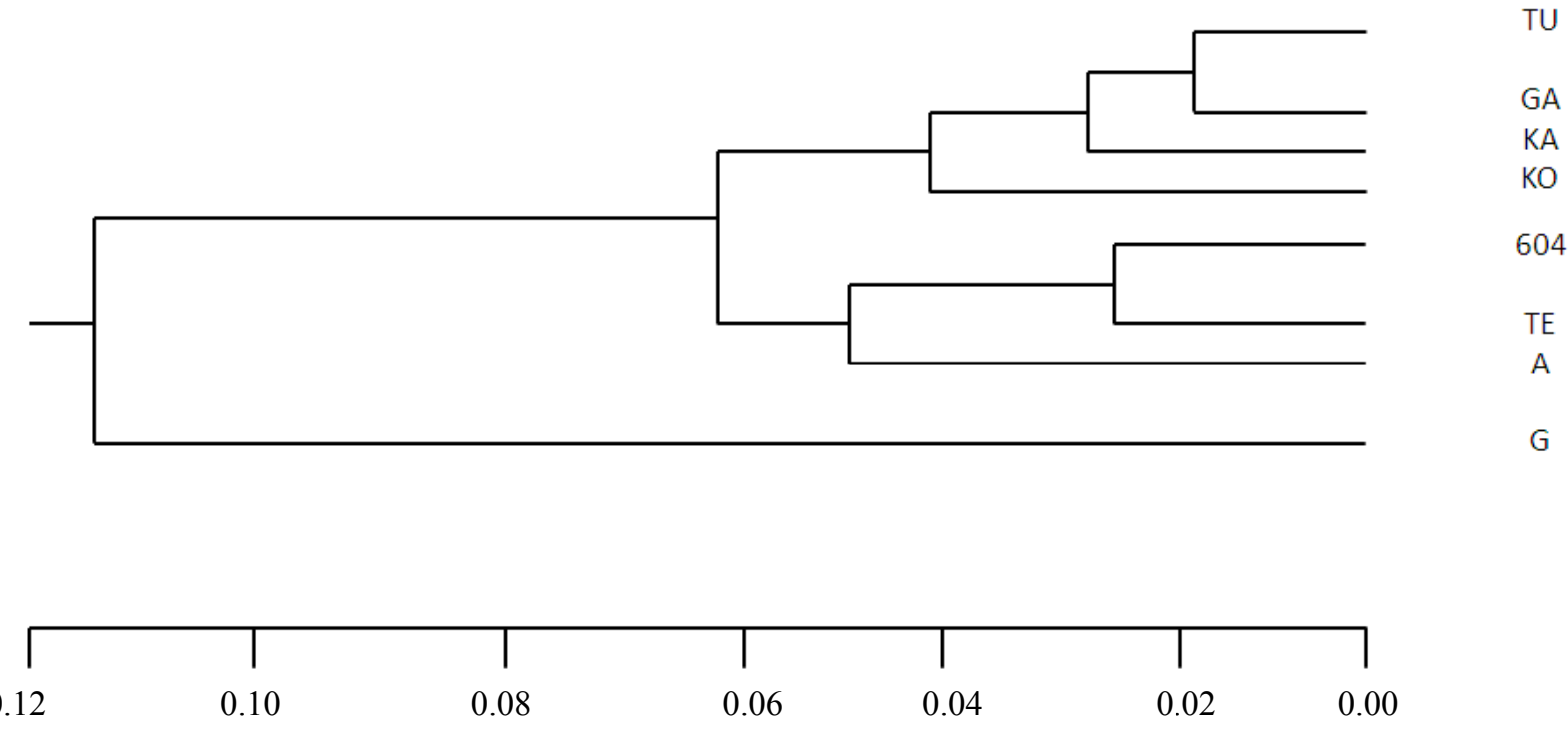

Fig. 2 PGI dendrogram constructed on the basis of gene frequency. 


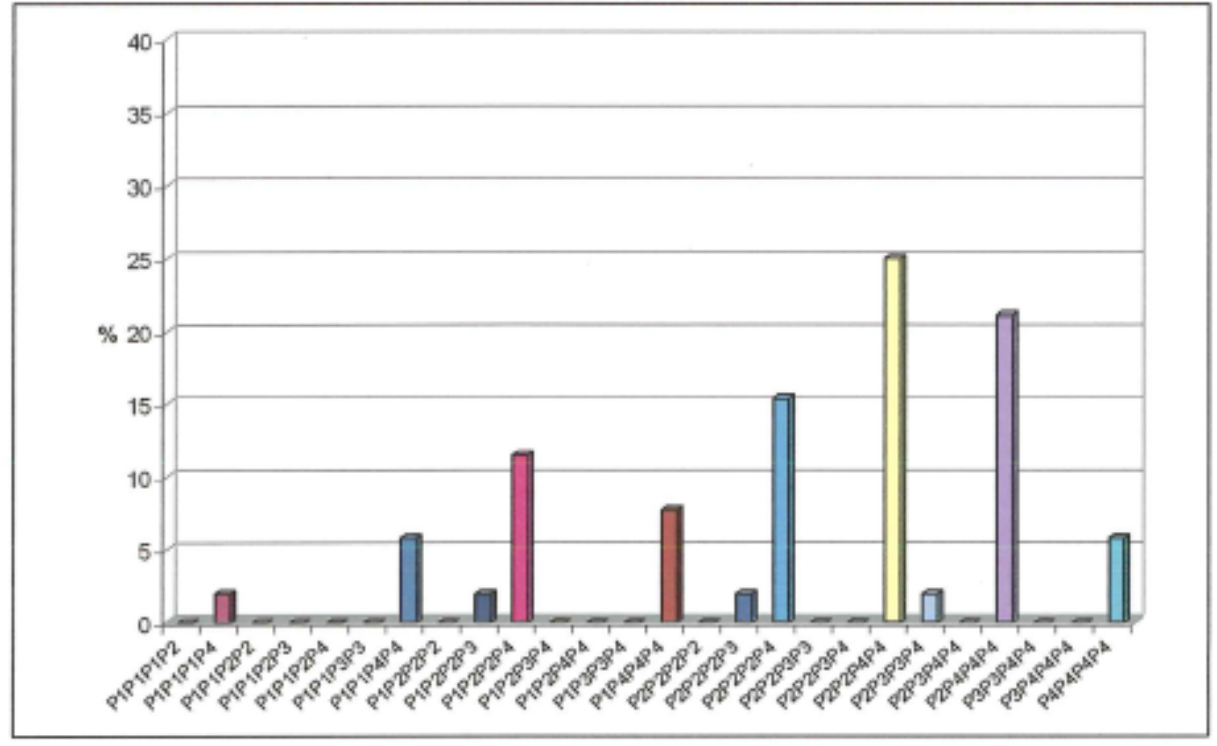

Gaza

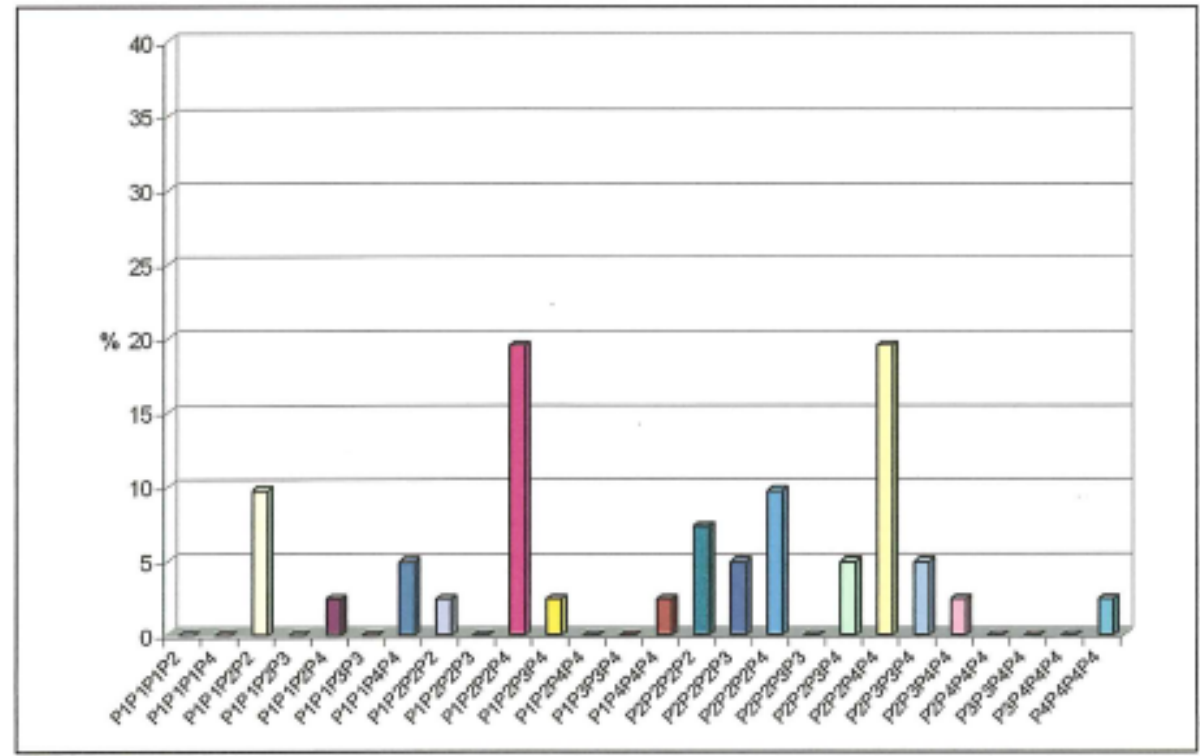

Telga

Fig. 3 Histograms of the PGI phenotypes generated for L. multiflorum (GA) and L. westerwoldicum (TE).

ISSR 01, 50 for ISSR 02, 55 for ISSR 04, 38 for ISSR 06 and 52 for ISSR 07. Electrophoretic separation of PCR products was shown in Fig. 4. The studied cultivars are clearly polymorphic at the DNA level. In the analysed material, no specific products (markers) were found for individual cultivars. The dendrogram (Fig. 5) generated for 64 individuals suggests that three groups of samples can be distinguished. The first group is created by KA and G, the second by cultivar 604 with TU and the third one is initiated by GA, TE, $\mathrm{A}$ and KO. The most marginal populations are occupied by KA and KO. It is noteworthy that two cultivars of L. westerwoldicum, $\mathrm{KO}$ and $\mathrm{TE}$ are included to the same group. 


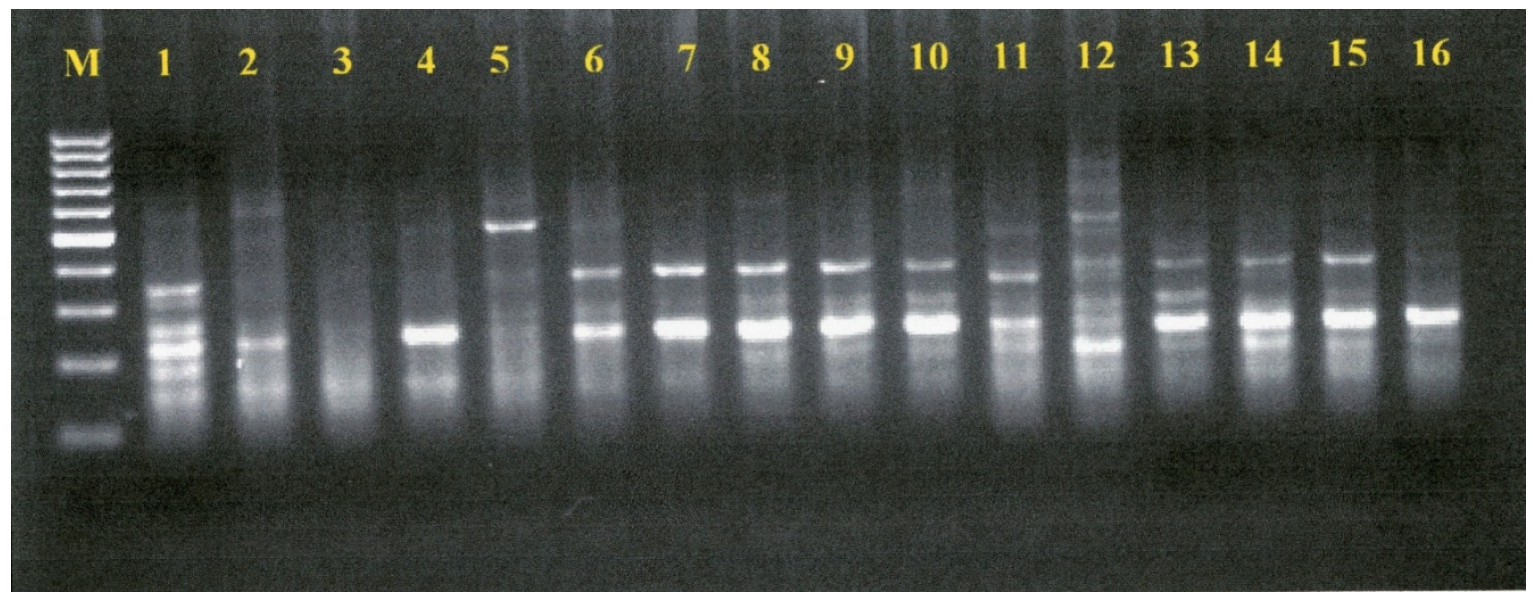

Fig. 4 Electrophoretic patterns of PCR-amplified ISSRs on 1.5\% agarose gels. M-100 pz markers, starter ISSR 04 (ATG) 6 ; 1-6: cultivar KA; 9-16: cultivar G.

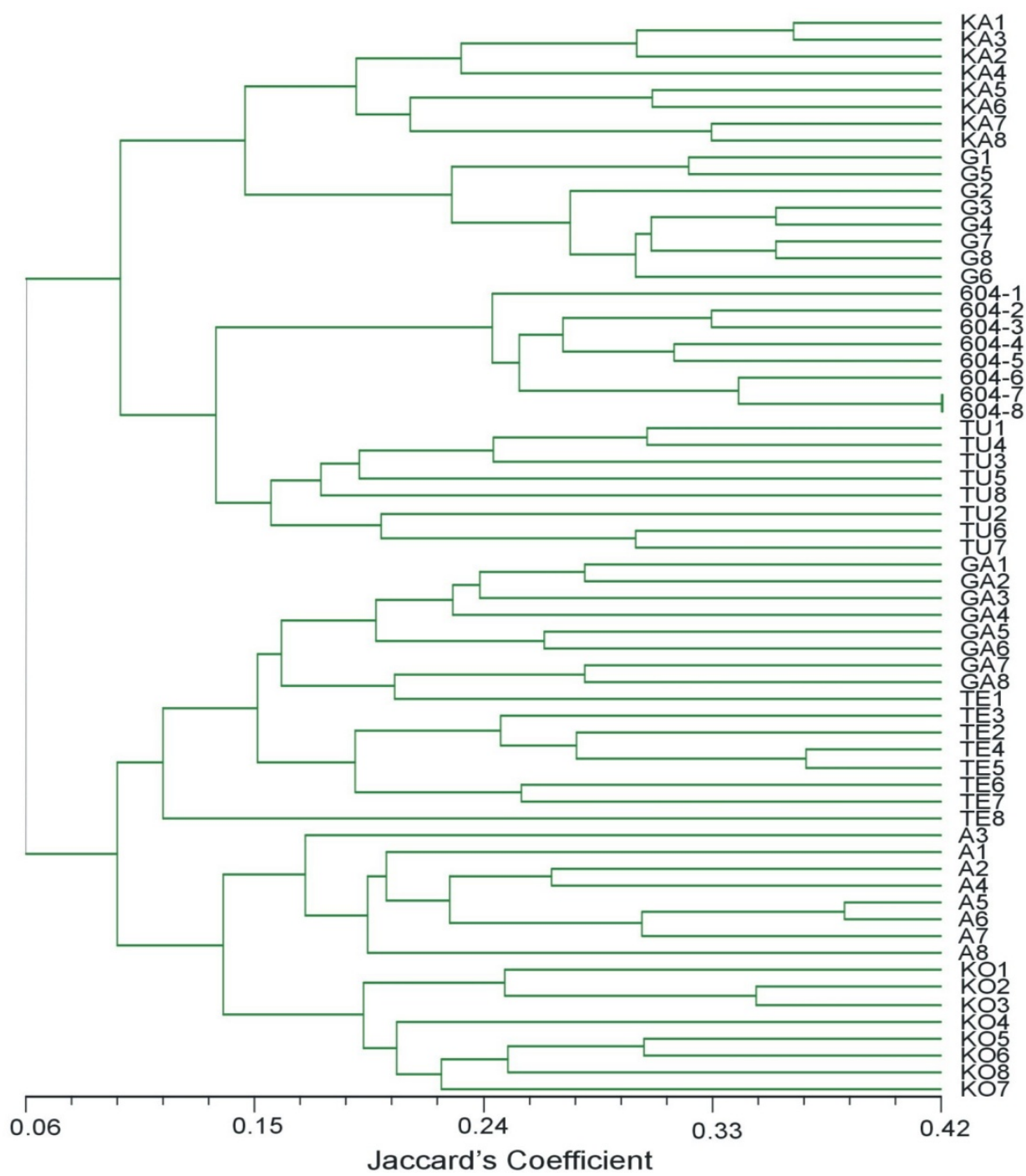

Fig. 5 Dendrogram from cluster analysis (UPGMA) based on Jaccard's genetic distances constructed for 64 OTUs. 


\section{Conclusions}

All the compared Polish cultivars of L. multiflorum show genetic polymorphism. Out of the five studied enzyme systems, the most polymorphic ones were PGI and PX. This is interesting because both enzymes are involved in processes of plant resistance, so the knowledge of their genetic variation can be of practical importance. Broadening of research on those enzymes may provide new information on variation of the species.

In this study, ISSR-PCR proved to be useful for analysing associations between Lolium cultivars, although no markers specific to any cultivar were identified. In total, 401 plants were analysed simultaneously with the use of biochemical and molecular markers.

\section{Acknowledgments}

Skillful technical assistance of Mrs. Barbara Malchrowicz is fully appreciated.

\section{References}

[1] Vieira, E. A., Castro, C. M., Oliveira, A. C., Corvahlo, F. I., Zimmer, P. D., and Martins, L. L. 2004. "Genetic Structure of Annual Ryegrass (Lolium multiflorum) Populations Estimated by RAPD." Sci. Agric. (Piracicaba, Brazil) 61 (4): 407-13.

[2] Inue, M., Gao, Z. S., Hirata, M., Fujimori, M., and Cai, H. W. 2004. "Construction of a Higher-Density Linkage Map of Italian Ryegrass (Lolium multiflorum Lam.) Using Restriction Fragment Length, Amplified Fragment Length Polymorphism and Thelomeric Repeat Associated Sequence Markers." Genome 47 (1): 57-65.

[3] Hirata, M., Cai, H., Inoue, M., Yuyama, N., Miura, Y., Komatsu, T., Takamizo, T., and Fujimori, M. 2006. "Development of Simple Sequence Repeat (SSR) Markers and of an SSR-Based Linkage Map in Italian Ryegrass (Lolium multiflorum Lam.)." Theor. Appl. Genet. 113 (2): 270-9.

[4] Inue, M., and Cai, H. W. 2004. "Sequence Analysis and Conversion of Genomic RFLP Markers to STS and SSR Markers in Italian Ryegrass (Lolium multiflorum Lam.).” Breed Sci. 54: 245-51.

[5] Quian, W., Ge, S., and Hong, D. Y. 2001. "Genetic Variation within and among Populations of a Wild Rice
Oryza granulata from China Detected by RAPD and ISSR Markers." Theret. Appl. Genet. 102 (2-3): 440-9.

[6] Joshi, S. P., Gupta, V. S., Aggawal, R. K., Raujekar, R. K., and Baar, D. S. 2000. "Genetic Diversity and Phylogenetic Relationship as Revealed by Inter Simple Sequence Repeat (ISSR) Polymorphism in the Genus Oryza." Theor. Appl. Genet. 100 (8): 1311-20.

[7] Girma, G., Tesfaye, K., and Bekele, E. 2010. "Inter Simple Sequence Repeat (ISSR) Analysis of Wild and Cultivated Rice Species from Ethiopia." African Journal of Biotechnology 9 (32): 5048-59.

[8] Matos, M., Pinto-Carmide, O., and Benito, C. 2001. "Phylogenetic Relationship among Portuguese Rye Based on Isozyme, RAPD and ISSR Markers." Hereditas 134: 229-36.

[9] Grądzielska, A., Gruszecka, D., and Paczos-Grzęda, E. 2010. "Evolution of Hybrids between Triticale and Aegilops crassa Applying RAPD and ISSR Methods." Folia Pomer. Univ. Technol. Stetin. 276: 19-30.

[10] Kramek, A., and Paczo-Grzęda, E. 2010. "Estimation of Genetic Diversity of the Polish Winter Triticale Cultivars Using the ISSR Markers." Zeszyty Problemowe Postepów Nauk Roniczych 555: 249-58. (in Polish)

[11] Tanyolac, B. 2003. "Inter Simple Sequence Repeat (ISSR) and RAPD Variation among Wild Barley (Hordeum vulgare Subsp. spontaneum) Populations from West Turkey." Genet. Res. Crop Evol. 50 (6): 611-4.

[12] Sutkowska, A., and Mitka, J. 2005. "Molecular PCR-ISSR Analysis in Bromus Subgenus Festucaria-Preliminary Results." In Biology of Grasses, edited by Frey, L., 207-16.

[13] Kozłowski, S., and Goliński, P. 1994. "Quantitative Evaluation of Polish Lolium westerwoldicum Cultivars." Genet. Pol. 35: 233-9. (in Polish)

[14] Krzakowa, M. 2011. "Genetic Diversity of Italian Ryegrass Diploid Cultivars, Revealed by Electrophoretically Detected Genotypes in Phosphoglucose Isomerise (PGI)." Journal of Agricultural Science and Technology 1: 778-82.

[15] Bennett, S. J., Hayward, M. D., and Marshall, D. F. 2002. "Electroforetic Variation as a Measure of Species Differentiation between Four Species of the Genus Lolium." Genetic Resources and Crop Evolution 49 (1): 59-66.

[16] Warnke, S. E., Baker, R. E., Brilman, L. A.,Young III, W. C., and Cook, R. L. 2002. "Inheritance of Superoxide Dismutase (SOD-1) in Perennial $\times$ Annual Ryegrass Cross and Its Allelic Distribution among Cultivars." Theor. Appl.Genet. 105 (8): 1146-50.

[17] Nei, M. 1972. "Genetic Distance between Populations." Amer. Natur. 106 (949): 283-92. 

as Revealed by Enzyme and ISSR Polymorphism

[18] Stepansky, A., Kowalski, I., and Perl-Treves, R. 1999. "Inter-Specific Classification of Melons (Cucumis melo L.) in View of Their Phenotypic and Molecular Variation." Plant Syst. Evol. 271: 313-32.

[19] Rohlf, F. J. 2002. NTSYSpc: Numerical Taxonomy and Multivariate Analysis Version 2.11a. Setauket, N.Y.: Exeter Publishing Ltd., 171.

[20] Krzakowa, M., and Mikulski, W. 1996. "Peroxidase as Marker in Pure Lines of Perennial Ryegrass (Lolium perenne L.)." In Proceedings of the 20th Meeting of EUCARPIA Fodder Crops and Amenity Grasses Section "Ecological Aspects of Breeding Folder Crops and Amenity Grasses”, edited by Staszewski, Z., Młyniec, W., and Osiński, R. Radzików, Poland: Plant Breeding and Acclimatization Institute, 320-4.

[21] Krzakowa, M., and Dunajski, M. 2007. "Genetic Differences and Hybridization between Calamagrostis arundimacea and C. villosa (Poaceae) in Anemo-Orographic (A-O) System in Karkonosze Mountains." Biochemical Systematics and Ecology 35 (1): 23-8.

[22] Krzakowa, M. 2011. "Phosphoglucoisomerase (PGI) as a Marker of Intra-Specific Differences in Grasses (Poaceae)." In Essays on Agriculture and Environment, edited by Maleviti, E., and Stathopoulos, C. Athens Institute for Education and Research, 29-33. 